\title{
Heretical Innovation of Distorted Beliefs (Bid'ah Dalalah) and Superstitious Practices Among Muslim Society in Malaysia
}

\author{
Fadzli Adam ${ }^{1}$, Firdaus Khairi Abdul Kadir ${ }^{2}$, Syed Hadzrullathfi Syed Omar ${ }^{1}$, Zawawi Yusoff ${ }^{3} \&$ Wan Hishamudin \\ Wan Jusoh ${ }^{3}$ \\ ${ }^{1}$ Research Institute for Islamic Products and Civilization, Universiti Sultan Zainal Abidin, Malaysia \\ ${ }^{2}$ Centre for Fundamental and Liberal Education, Universiti Malaysia Terengganu, Malaysia \\ ${ }^{3}$ Faculty of Islamic Contemporary Studies, Universiti Sultan Zainal Abidin, Malaysia \\ Correspondence: Fadzli Adam, Research Institute for Islamic Products and Civilization (INSPIRE), Universiti \\ Sultan Zainal Abidin, 21300 Kuala Terengganu, Malaysia. E-mail: fadzliadam@unisza.edu.my
}

Received: April 28, 2015 Accepted: June 1, 2015 Online Published: August 18, 2015

doi:10.5539/ass.v11n24p147 URL: http://dx.doi.org/10.5539/ass.v11n24p147

\begin{abstract}
The teaching of Islam has warned and reminded Muslim society regarding the threat of superstitious practices after the period of the Prophet Muhammad (peace be upon him). Various distorted beliefs, such as shamanism and fortune-telling, have simultaneously spread all over the Muslim world including Malaysia. Among several causal of heretical innovation of distorted belief is ignorance and lack of religious knowledge. This article higlights contributing factors of Malays' involvement in superstitious practices which stresses on their perception, beliefs and practices. The writing of this article is based on the study conducted through qualitative methods using observation and interview. Selected key informants from religious affairs departments and political leadership are selected as respondents of the study. The result found that lack of religious education, ignorance, the influence of shamanism and strong belief in mystic and magic are accepted to contribute to the occurence of superstitious practices. These causal factors need to be addressed in the very best possible manner by the Islamic affairs authorities in order to prevent futher society involvement.
\end{abstract}

Keywords: Bid'ah Dalalah, Superstition, Heretical Innovation, Distorted Belief, Malay Society, Islam

\section{Introduction}

\subsection{A Brief Introduction on Heretical Innovation of Distorted Beliefs (Bid'ah Dalalah) and Superstitious Practices}

Distorted beliefs and practices are the manisfestations of the existence of the Jahiliyyah Arab society before the dawning of Islam. The Prophet Muhammad (pbuh) was aware of instances of distortion of faith would begin with new practices that would contradict the Islamic faith and Islamic law. Thus, the Prophet (pbuh) was reported to have said that all new practices are heretical innovations to avoid spiritual and syariah deviation for the last generations of the ummah (Abd-Allah, 2006). The debate about the matter was even discussed by Muhammad al-Ghazali in his kitab (book) Laisa min al-Islam. He too mentioned about the phenomena of the spread of the distorted beliefs and heretic innovations across Arabia such as the emergence of several deviant spiritual groups.

In the Malaysian context, this phenomena is also presented to the 40th Discourse of the National Fatwa Committee for Islamic affairs of Malaysia on the 9th August 1996. The committee had discussed the topic of distorted beliefs and talisman from the Islamic perspective. The discourse finally decided that the practice of worshipping and seeking help as practiced by the shamans are considered acts of polytheism. In addition, the use of talismans for self-protection to be invincible, to gain influence, to soften the heart, to keep away the jinns and the likes are also considered as acts of polytheism and deviating from the basic teachings of Islam (e-Fatwa, 1996).

The above mentioned practices are in concordance to the practices of seeking the shamans and believing in the power of talisman. According to (Abdul Manam, 2008), among the shamans, there are those who deviate in their practices and actions such as the worshipping of the spirits, use of dirty and forbidden substances and beliefs which are against the Islamic faith and Islamic law. In addition, as Abdul Fatah (1999) notes, the Malay society 
is easily exposed to the spiritual influence which may result in the deviant form of Islamic faith. Spiritual influence referred to here including worship particular places considered holy, or persons considered saints and the belief that the shamans have absolute power. These practices are classified as heretical innovation of distorted beliefs. The emergence of this beliefs results in the appearance of various deviant teachings among the Malay community such as the teachings of Ayah Pin, Al-Arqam and so on. With such a background, the Malay community is readily exposed to negative elements that would soon result in the erosion of the Islamic faith of the ummah. If this phenomena is not curtailed, the risk of the deviation of faith through the spread of various deviant ideologies is higher and will be more difficult to overcome. Therefore, this article aims to highlight some points of view from several authorized key informants on issues related to heretical innovation of distorted belief and its relationship with superstitious practices among Muslim in Malaysia

\subsection{Heretical Innovation of Distorted Beliefs and Superstitious Practices from Muslim Scholars' View}

This issue has been widely discussed and analysed by local and international scholars via several articles and research undertaken. Amongst them is al-Qaradawi (1995) who stated that heretic innovations from the aspect of Islamic faith had already emerged. The heretic innovations he referred to are that violate the basic tenets of Islamic faith. What seems to be worrying is that such distorted beliefs would also be potential threats to the faith of the Muslim society since the emergence of several sects that seemed to encourage them as pointed out by al-Qaradawi (1992) with regards to the existence of three sects capable of destroying the Sunnah which are:

i. Religious extremist group that deviates from the teachings of the Prophet Muhammad (pbuh). The followers tend to be extreme in their religious rituals and practices.

ii. Attempts by people who are ignorant or deviant in explaining the rules and tenets of the Islamic faith. More often than not, they tend to bring about innovations into their religious practices.

iii. Reasoning used by those who are ignorant about the religion. This group tends to interpret the religion devoid its Islamic spirit. Usually they physically appear as great scholars of Islam.

According to al-Sharqawi (2002), distorted beliefs have existed even before the dawn of Islam. As such, The Prophet (pbuh) has strongly warned against any form of distorted beliefs during his time. As an example, with regards to beliefs of birds bringing bad luck, talisman, fortune-telling and so on, the Prophet (pbuh) was narrated to have said :

There's no such thing as bad luck in birds, And that which is best is "al-fa'lu". The companions then asked, "What is al-fa'lu?. The Prophet (pbuh) quickly responded "good words or sayings that will be heard by someone amongst you"

The above Hadith clearly shows that the phenomena of distorted beliefs has flourished even before the coming of Islam. The attempts to eradicate these distorted practices had been done by the Prophet (pbuh) himself with the prohibition of such distorted beliefs as birds that could bring forth bad luck, fortune-telling and so on. This culture of ignorance was unacceptable to the Prophet (pbuh), who, instead, introduced the al-fa'lu which is the encouragement of good words or sayings such as seeking help, protection or even treatment of illness from Allah as in the sentence meaning "Oh Saviour (Allah)".

Several research and discussions on the issues of heretic innovations and distorted beliefs had been undertaken locally. Amongst them is Stapa (2011) who stated that there are several causal factors for the appearance of distorted beliefs and practices among the Malay community. One of the factors is the form of Islamization in this region. In the advent of Islam in this region, most of the Malay communities embraced Islam after their rulers themselves had accepted the faith. This phenomena resulted in the faith being embraced en mass as such that the Islamic faith was embraced en-mass without much full awareness and deep understandings of the Islamic faith and way of life. During the Islamization process, the Malay community also brought forth their inherited ancient traditions and rituals such as the beliefs in various superstitions, spirits, guardians of nature and so on (Stapa, 2011). These are distorted beliefs which contradict the Islamic law. Ismail (2008) stated that the elements of distorted beliefs had appeared through animisme. Such belief is closely related to the spirits that thrived in the invisible worlds and would appear to aid the Shamans. Animisme is also related to the beliefs in natural spirits. The existence of these natural spirits is believed to aid humans from evil spirits or commonly referred as ghosts. However, Mokhtar (1977) explained that, natural spirits possess the power acquired through people with exceptional strength, pious persons, aristocrats, the warriors and so on. These spirits are believed to to possess the spirit and form like that of humans, the ability to eat and drink and also possess the feelings of anger and happiness. As such, these spirits must be served with "spirited rice" spirited tumeric rice. The tumeric rice is then poked with eggs and need to go through some "mantras" before it is served to the spirits. 
According to Engku Zaki (2007), there are several traditional practices that deviate from the true Islamic faith, some of which are the ritual of to avoid of mishaps when contstructing a house, a special ritual of massaging a woman's abdomen or womb during the 7th month pregnancy to facilitate delivery, removing bad luck rituals especially when dangerous or venomous creatures enter our houses and many more. These sorts of beliefs would obviously expose the Malay community to distorted practices if such beliefs are not quickly stopped or curtailed.

The discussions above show that research related to the source of the appearance of heretic innovations in Islamic faith can be traced to the distorted beliefs. Having said that, there are still many research gaps that need to be scrutinised such as the fact that the distorted beliefs culture seem to be allowed unchecked and widespread.

\section{Method}

A qualitative approach was used in this research. A few key informants were interviewed to understand their views on the issues. The choice of the informants was based on their expertise in the religious field and their involvements in social activities. There were also key informants chosen amongst government officers who were involved with reports and reference person for the community. Besides qualitative approach, this research had also utilised content analysis and observations to ensure that it will be more realistic in the current context.

\section{Results and Discussions}

The findings from this research found that there are four factors for the existence of distorted practices amongst the Malay community. The four factors are as follows:

\subsection{Lack of Religious Education/Upbringings}

Human behavior is very much influenced and formed based on his religious knowledge. As such, this would lead to the emergence of deviant practices such as the worshipping of particular places considered holy, idolization of personalities considered saints and worshipping of the sea. According to Basri (1997) among the contributors of heretic innovations are the debates on religion without ample knowledge in particular fields. Such debates would only cause the public to be dragged and drifted into the arguments without proper basis of faith. The effect from this is that the community will eventually drift and lost in the debates without a really sound religious education. The lack of religious education would expose the community to the threats of distorted beliefs that would lead them into heretic innovations in terms of faith (Basri, 1997).

One of the key informants from the Terengganu State Deputy Exco, Muhammad Ramli Nuh acknowledged this factor. He pointed out that amongst the Malay community there are those who do not acquire the true and correct knowledge to the extent that religious knowledge could not be disseminated to the Malay community. This happened due the lack of religious knowledge amongst the preachers themselves. Thus, religious authorities and scholars found it difficult to check the threats of deviant beliefs that emerge through various mediums. Rightfully, the religious expertise should equip themselves with various diciplines of knowledge, whether in the form of Islamic heritage or the modern form. This would indeed lead to the preachers being percieved as the ummah problem solver.

The Kelantan State Exco, Dr. Muhamed Fadzli Hasan on the other hand, noted that the Malay community do not possess the correct understandings of the Islamic teachings. He perceived that some goups of community view that whatever they have practiced thus far is in accordance to Islam. However, these practices are found to deviate from the boundaries of Islamic teachings and easily influenced by distorted beliefs threat. Another key informant from the Kelantan Religious Affairs Department, Noorlailawati Mamat viewed that the lack of religious education would result in the Muslim environment being easily influenced by external elements or forces.

The views and opinions of the these key informants are in accordance with the content analysis related to rituals of granting of blessings during wedding ceremonies. Such rituals prove the lack of religious understandings amongst the Malay community. They have adhered to these practices down the generations without any true basis. It is found that there is no religious basis for such practice, in fact it only leads to heretic innovation based on distorted beliefs (Mohd Syukri, 2008). What have been discussed thus far are the results of the lack of religious knowledge which would lead the society to continue living their lives astray without any clear religious guardian. This would certainly affect the community being exposed to heretic innovations in its faith.

\subsection{Ignorance}

The second factor identified is ignorance. The real truth has been camouflaged by ignorance due the inaccurate and wrong point of reference. The result from such incorrect knowledge and education has transformed the distorted beliefs and practices easily accessible. Based on Firdaus Khairi (2008), amongst the factors for the 
emergence of heretic innovation is ignorance of the Islamic law. Such ignorance has resulted in the Muslim ummah to maintain ancient practices even though without any religious basis. Engku Ahmad Zaki (2014) also claims that ignorance towards Islam as a contributing factor in the catastrophe of Islamic faith among Muslims which consequently, lead to the existence of deviant teachings.

The source of ignorance as acknowledged by one key informant, Dr Muhamed Fadzli Hasan, is that some of the Muslim ummah are entrapped in ignorance of religious knowledge. As a result, negative and deviant teachings have unawarely succeded to penetrate the new generation. He also viewed that the acculturation of distorted culture via various mediums such as television which has sowed negative implications when they reach adulthood.

Ignorance has also been recognised as a factor by the Kelantan State Mufti, Mohamad Shukri Mohad. According to him, ignorance caused the Muslim ummah to act beyond religious boundaries that contradicts with the Islamic law. He iterated that the true meaning of ignorance is not limited to one's ignorance about the worldly affairs but also the lack of the knowledge of hereafter. Such situation leads them to act beyond religious boundaries.

The other key informant, the Senior Deputy Director of Department of Islamic Affairs, Pahang, Badli Shah Alaudin explained that the existence of deviant teachings in this region is the effect of the ignorance of the Muslim ummah towards the true teachings of Islam. According to him, leaders of deviant teachings are able to influence the Muslim ummah through strategic and sistematic approach. At the same time, the Malay community is lured by negative culture that is being exposed to them through the various current mediums.

The negative implication as mentioned above is in accordance with the content analysis of Engku Zaki (2007). Based on his research, the television is identified as the contributor to the spread of deviant techings. The screening of negative elements via Satanic music such as Thrash \& Death and Heavy Metals are being introduced to the younger generations. The symbols of the skull, ghosts and splashes of blood printed on their shirts, chains, rings and so on were introduced to them via the media. All these have exposed the community to the negative culture leading to deviant beliefs and practices.

\subsection{Influence of the Belief in Shamanism}

Based on the researcher's observation, the third factor is the influence of Shamanism. In the Malay community, shamans have huge influence and quite high status or role in solving the community's problem. They offer their services for the treatment for all kinds of illnesses to the public. According to Firdaus Khairi (2008), amongst the contributing factors of deviant heretic innovation is the influence of magic and predictive knowledge. Often, this influence emerges from the methods of shamanism. These shamans possess the skills of predicting as a "weapon" to attract customers.

Such view is also shared by one of the key informants, Noorlailawati from the Kelantan State Religious Department. According to her, there were many reports about the services of the shamans that involved in distorted beliefs. She explained that the belief in Shamanism still exist and is often identified as the initiator to the distorted beliefs in the local community.

The argument for the shamans' influence in the Malay community is also shared by the Kelantan State Mufti who stated that there are shamans who contradicts Islamic law. Even there are shamans who tarnish the image of Islam by using Qur'anic verses to gain the customers' confidence and trust. According to another key informant, Dr. Muhamed Fadzli Hasan, shamans are easily tricked by the satan whose role is to break the husband-wife and community relationship. According to him, there are members of the community that perceive the shamans as having a very important role in solving any form of problems that they face. As an example, when experienced some health problems, the initial reference and preference would be the shamans rather than qualified doctors. This has led them to be exposed to the wrong methods of treatment of ailments which unfortunately lead the Muslim ummah to be entrapped in the distorted and polytheist practices via shamanism.

This factor is also aknowledged in the content analysis about the methods of shamanism within the Malay community. According to Engku Zaki (2007), the influence of shamans is very strong within the Malay community. Some shamans are even granted the role to lead religious rituals, preparation of "medicinal water", talismans, protection from mishaps, worshipping of spirits and so on. At the same time, there are shamans who empasize on the use of "magical or invisible" powers to diagnose illnesses suffered by patients that are believed to be related to external invisible powers.

\subsection{Belief in Mysticism and Magic}

The fourth factor is the influence of the belief in myticism and magic. This factor is also acknowledged by another key informant, the Kelantan State Mufti. He opined that the Malay community is often related to the 
belief in magics. With such beliefs which is perceived to be magical and perculiar is often honoured by its enthusiasts. Zulkifli as quoted in Firdaus Khairi (2008) also shares the same opinion about this factor who stated that there are amongst the Malay community those who perceive religion as something extraordinary. As such, there are some members of the Malay community who explore spiritual knowledge and mysticism with the excuse of deepening their own religious knowledge. Often, at the end of their journey into mysticism they find themselves entrapped in deviant teachings (Philips, 2005). Soon, they start worshipping their teachers to the level of sinless from any form of wrongdoings.

The source of belief in mysticism and magic is also shared by several key informants, including the Kelantan State Mufti who stated that the Malay community is often related to the beliefs in magics. Such beliefs lead to certain things perceived as extraordinary or magical being worshipped by its enthusiasts. This phenomena occurs in the Malay community without any serious prohibitions to the extent that something magical is perceived as of higher additional value.

In explaining the issue of mysticism and magic, Badli Shah Alauddin stated that one of the sources is the community's inclination to interact with external invisible or spiritual world such as interracting with the strange powers in the forests, seas, oceans and so on. According to him, the situation has worsened and become more difficult as some preachers themselves hold to the beliefs in mysticism and magic. Such actions and behaviors indirectly endorse the continuity of distorted beliefs practices within the Malay community.

The belief in mysticism and extraordinary is also supported by the discussion in a writing on Crypto teachings. The research found that the Malay community is proned to be influenced by someone who is able to portray as possessing extraordinary or magical power. As an example, in the Crypto teachings, a teacher often exhibit magical powers to his or her followers such as the ability to jump up 10 feet while performing the Malay art of self-defence and the skills of making predictions (Muhammad \& Abdullah, 1983).

\section{Conclusion}

As a conclusion, it can be deduced that all the four factors as discussed in this article are the major sources identified as the catalysts to the spread of heretic innovations in the Islamic faith. These four sources need to be checked by the relevent authorities and the whole Muslim ummah as well. If these sources are allowed to flourish in the Malay community, it might cause concern that these would result in serious impacts on the faith of the Muslim ummah. The lack of religious knowledge, ignorance, influence of Shamanism and the belief in mysticism and extraordinaries should be checked and curtailed in the best way. All the preachers should be creative in their approaches when interacting with those involved in distorted beliefs. The use of unwise approaches will result in their noble attempts to be perceived and responded coldly by those involved. It should be reminded that the bigger impact from distorted beliefs is the threats from heretic innovations in the Islamic faith capable of shakening the faith of the Muslim society.

\section{References}

Abd-Allah, U. F. (2006). Innovation and Creativity in Islam. Burr Ridge: The Nawawi Foundation

Abdul Fatah Haron, I. (1999). Pengaruh Kebatinan Dalam Masyarakat Islam Di Malaysia. Kuala Terengganu: Yayasan Islam Terengganu.

Abdul Manam, M. (2008). Penyelewengan Akidah Dan Perbomohan: Ciri-ciri, Faktor dan Implikasi Terhadap Umat Islam. Kuala Terengganu: Yayasan Islam Terengganu.

al-Qaradawi, Y. (1992). Madkhal li Dirasah al-Sunnah al-Nabawiyyah. Qaherah, Mesir: Maktabah Wahbah.

al-Qaradawi, Y. (1994). Mauqif al-Islam min Ilham wa al-Kashaf, wa al-Ruqya, wa al-Tamaim, wa al-kuhanah wa ruqa. Kaherah. Mesir: Maktabah Wahbah.

al-Qaradawi, Y. (1995). Fi Fiqh Al- Aulawiyyat wa Dirasatu al-Jadidah fi Dhau' al-Quran wa Sunnah. Qaherah, Mesir: Maktabah Wahbah.

al-Sharqawi, A. (2002). Al-Ahadith al-Mukhtarah min Fathu al-Mubdi'. Selangor: Al-Azhar dan Kementerian Pelajaran Malaysia.

Basri, I. (1997). Khilafiyyah, Bid'ah \& Maslahah Umum. Kuala Lumpur: Darul Nu'man.

e-Fatwa, J. (1996). e-Fatwa. Retrieved March 24, 2013, from http://www.e-fatwa.gov.my

Engku Ahmad Zaki, E. A. (2007). Ajaran Sesat: Mengenali Jalan Yang Terpesong. Batu Caves, Selangor: PTS Islamika.

Engku Ahmad Zaki, E. A. (2009). Ajaran Sesat Di Negeri Terengganu. Kuala Terengganu: Penerbit UDM. 
Engku Ahmad Zaki, E. A. (2014). Islamic Faith in Malaysia: Current Issues and Challenges. Mediterranean Journal of Social Sciences, 5(20). http://dx.doi.org/10.5901/mjss.2014.v5n20p1954.

Firdaus Khairi, A. K. (2008). Bidaah Dalalah. Kuala Tererngganu: Majlis Agama Islam dan Adat Melayu Terengganu (MAIDAM).

Firdaus Khairi, A. K. (2009). Bid'ah Dalalah dalam Kalangan Masyarakat Melayu Di Terengganu. Unpublished Masters Thesis, Universiti Malaysia Terengganu.

Harian, B. (2011, October 5). Berita Harian. Kuala Lumpur, Wilayah Persekutuan, Malaysia: Berita Harian.

Ismail, H. (2008). Masyarakat dan Budaya Melayu. Kuala Lumpur: Dewan Bahasa Dan Pustaka.

Mausuah Fiqhiyyah al-Kuwaiti. terjemahan Firdaus Khairi Abdul Kadir. (2008). Bidah: Kupasan Berdasarkan Ensiklopedia Fekah. Kuala Terengganu: Majlis Agama Islam dan Adat Melayu Terengganu (MAIDAM).

Mohd Syukri, Y. (2008). Bid'ah: Kekeliruan Agama dan Adat. Kuala Terengganu: Yayasan Islam Terengganu.

Mokhtar, M. D. (1977). Kepercayaan-kepercayaan Orang Melayu Dahulu Kala. Selangor: Federal Publication.

Muhammad Jusoh, A. M. (1983). Ajaran Crypto. Jurnal MASA, Pusat Penyelidikan Islam Malaysia, 1-10.

Philips, A. A. B. (2005). The Fundamentals of Tawheed (Islamic Monotheism). Riyadh: International Islamic Publishing House.

Stapa, Z. (2011, June 30). Amalan Dan Kepercayaan Khurafat Dan Tahyul Dalam Masyarakat Melayu. Wacana Pendidikan Fatwa. Kuala Terengganu, Terengganu, Malaysia: Universiti Kebangsaan Malaysia.

\section{Copyrights}

Copyright for this article is retained by the author(s), with first publication rights granted to the journal.

This is an open-access article distributed under the terms and conditions of the Creative Commons Attribution license (http://creativecommons.org/licenses/by/3.0/). 